\title{
Maturity of IT systems supporting communication processes in HCM in a modern organization
}

\author{
Andrzej Sołtysik \\ University of Economics in \\ Katowice \\ ul. 1 Maja, 40-287 Katowice, \\ Poland \\ Email: \\ andrzej.soltysik@ue.katowice.pl
}

\begin{abstract}
The aim of this paper is to analyze available maturity models in the context of assessment of the maturity of IT systems that support communication processes in HCM. The paper presents theoretical issues connected with the evolution of information systems in context of support Human Capital Management (HCM) in a modern organization. Selected problems connected with assessment of maturity were presented, and examples of models for maturity assessment were analyzed in the context of their use for evaluation of HCM Information Systems. As a conclusion, the paper indicates necessity to create a new dedicated method for assessing maturity of the systems analyzed.
\end{abstract}

\section{INTRODUCTION}

$\mathrm{M}$ ODERN organizations still search for tools that would be able to ensure them advantage over their competitors. A necessary condition for an efficient functioning of an organization is the use of all kinds of solutions that will enable optimization and improvement of processes taking place in an organization. In the context of the development of an organization, it is especially important to support basic processes aimed at knowledge acquisition and processing as well as its skilful use in practice.

Employees of an organization may turn out to be the basic factor guaranteeing its development and achievement of advantage. For performance of tasks assigned by managers, employees use available knowledge. Knowledge can be acquired, processed and distributed as a result of creation and maintenance of efficient communication channels, both within an organization and between an organization and its environment. The use of mature IT systems supporting the performance of communication processes makes it easier to fulfill this task. As a result of these changes, traditional organizations turn into knowledge-based organizations and concentrate their activities on human resources, that are the most important of immaterial resources at the disposal of an organization.

The first part of the paper will discuss the evolution of the role fulfilled by employees in a modern organization, from human resources to emergence of human capital. Further, the paper will discuss tools supporting the performance of communication processes in HCM in an organization, with particular reference to IT systems.

Next, it will analyze preliminary results of research on IT systems designed to support processes of human capital management in Polish organizations. Next part will feature a review of several models in the context of evaluation of the maturity of IT systems designed to support communication processes in HCM.

\section{EVOLUTION OF THE ROLE OF EMPLOYEES IN A MODERN ORGANIZATION}

Not so long ago, employees were treated as one of the resources that an organization acquired and had at its disposal. For those managing an organization, it was important that the individual resources, including human ones, were at a specified level [1]. Management of human resources was concentrated mainly on the quantitative and economic aspect of managing staff - the so-called "hard HRM" [2]. HR managers mainly dealt with administration of remuneration, handled all the issues connected with labour law, management of an organization and working time [3]. Attention was paid to employees' skills - including even the definition of the level of competencies required for employment at a specific - but their use was optimized by managers by means of traditional methods and techniques covering acquisition, development and use [4], [5].

Most modern theories of HR management definitely depart from treating employees like objects. This new approach is based on the concept of the so-called soft HRM proposed in work [3]. The soft HRM makes employees committed to their work by encouraging them to identify with the objectives and mission of the organization and by involving them in defining further tasks [1]. A HR strategy more and more often recognizes and takes into account employees' talents, becoming the foundation of a modern view of the role of people in an organization. Human capital plays a key role in every organization, determining the differences between organizations and constituting the actual basis for competitive advantage [6]. Appropriate people can be the fundamental success factor, but inappropriate ones may contribute to failure of an organization. Summing up: human capital mainly involves 
the knowledge of an organization's members, their skills, experience, ability to solve problems, willingness to create and introduce innovations [7], qualifications, creativity and loyalty towards an organization. The human capital at the disposal of an organization should be efficiently managed, which requires the use of reliable tools supporting the basic processes related with this task. Human capital management (HCM) is a set of practices related to people resource management. These practices are focused on the organizational need to provide specific competencies and are implemented in three categories: workforce acquisition, workforce management and workforce optimization.

\section{TOOLS DESIGNED TO SUPPORT THE PERFORMANCE OF COMMUNICATION PROCESSES IN HCM IN AN ORGANIZATION}

In the free-market economy, the impact of the external environment and conditions of operation are similar for all organizations. Basically, all organizations competing on the market have free access to employees and supporting technology. In such a situation, the main factor determining an organization's competitive advantage is acquisition, creation and appropriate use of its human capital. In order to be able to fully use employees' potential, it is necessary to not only ensure their development, but also to try to make the most valuable of them stay in the organization. We should, however, bear in mind that all organizations can support employees using generally available solutions for that purpose.

Efficient performance of basic processes connected with human capital management requires the use of various available solutions and technologies. Particular emphasis should be placed on systems designed to support broadly understood communication processes. As a response to this demand, more and more IT solutions are created to support the performance of processes connected with human capital management. The use of the latest IT technologies supports learning processes, and the traditional HR processes implemented by an organization are transformed into knowledge-based HCM processes, which leads to the emergence of a new model of an employee, the so-called knowledge worker. Employees' knowledge, skills, abilities, motivation and values are becoming increasingly important and constitute the basic element determining the role of people and related human capital in a modern organization [8]. Without IT support, process improvement may take too long to perform traditional activities connected with administration of a large amount of paper documentation, training materials, instructions describing the performance of assigned tasks, reports or current HR and payroll documents. Implemented IT systems are expected to unify HR processes, systematize the work of the HR department, and support managers in managing subordinate teams. [9]

Employees of an organization more and more often have basic or extended knowledge of modern IT technologies. This knowledge is necessary to fully take advantage of the potential offered by the different technologies. Although there is growing awareness of the role fulfilled by these technologies in supporting communication processes connected with HCM, organizations should take actions aimed at improvement of their employees' competencies connected with the use of such technologies.

This thesis is confirmed e.g. by results of a survey concerning applications of selected modern IT technologies in the different processes connected with acquisition, creation and maintenance of human capital in a knowledgebased organization. The quantitative studies were conducted at the beginning of 2015 by the technique of paper questionnaire interviews (PAPI), on a randomly selected sample of 196 people at different ages, with different place of residence, education and employment relationship. The group consisted of students and graduates of I degree and II degree full-studies and post-graduate studies. Although the studies were conducted mainly in the territory of Silesia, the respondents came from or lived in different regions of the country and abroad.

Results of the studies show that the use of solutions designed to support communication processes is quite widespread in Poland. Of 196 respondents, 121 people ( $61.73 \%$ of the sample) were employed at the moment the survey was conducted. Of those employed, as many as 117 ( $96.69 \%$ of all those employed) declared that their employer had a corporate website or a different service supporting information exchange. Slightly fewer, i.e. 92 employers (76\%) used a computer network or advanced IT systems. 56 respondents $(46.28 \%$ of all employees) declared that their organization had mechanisms in place to enable exchange of knowledge with its environment. 32 of them $(62.75 \%$ of all employees) claimed that their employer had or planned to implement in the near future procedures or agreements the subject of which was acquisition, creation or exchange of knowledge with other enterprises or external institutions. 51 respondents $(42.15 \%$ of all employees) declared that their organization acquired, shared and exchanged knowledge with its environment apart from performing basic business processes. Of this group, 28 people $(23.14 \%$ of all employees) definitely declared that their organization was focused on knowledge management processes, noticing at the same time the need to use IT solutions to support these activities.

The same studies also revealed which of the IT systems had the largest potential in supporting processes connected with HCM. Processes connected with HCM in an organization were divided into three areas:

- acquisition of human capital

- creation, development and improvement of human capital

- maintenance of human capital.

The studies conducted confirmed the dominating role of solutions supporting processes connected with internal and external communication in all three areas of HCM. 
In processes connected with acquisition of human capital, local and wide area computer networks as well as solutions whose operation is directly based on them (Internet) $(77.78 \%)$ are most significant according to respondents. Business social networks such as Goldenline or Linked in, as well as discussion groups $(77.78 \%)$ were rated as the most important. Slightly less useful (75.56) are, according to respondents, traditional recruitment portals and social networks (Facebook, Twitter,...) as well as interface agents which are often encountered on various services in the form of virtual advisers. Respondents were equally interested in agent solutions used to search for information (62.22\%) and agent solutions used to search the Internet (66.67\%).

In processes connected with creation of human capital, a particularly important role was played by IT systems that used computer networks $(82.22 \%)$. Of similar importance are traditional social networks, followed by discussion groups $(77.78 \%)$, which in this context enable exchange of knowledge between their users, and interface agents that support training processes.

In the third area, significant importance of social networks, or virtual advisers (71.11\%) was highlighted in processes connected with maintenance of human capital. Social networks facilitate knowledge distribution and exchange with the environment, whereas interface agents support users using knowledge possessed by an organization Respondents showed slightly lower trust in discussion groups supporting information exchange (68.89\%).

Currently, the situation on the market of IT solutions designed to support the performance of processes connected with HCM is increasingly better. Producers deliver an increasing number of less or more advanced IT systems that use all available IT technologies. However, only "the best", most tailored IT systems can meet an organization's expectations. It is thus very important to possess reliable tools for evaluation of applied software to identify its strengths and weaknesses. Well adjusted tools can fully support processes connected with HCM.

\section{EVALUATION OF THE ADEQUACY OF IT SYSTEMS USED TO SUPPORT COMMUNICATION PROCESSES IN HCM}

The key to achievement of effective HCM is to ensure efficient knowledge distribution; it is necessary to make communication channels available and to involve employees in cooperation using these channels. Recognizing the necessity to improve the performance of the different processes connected with reliable communication channels for information exchange as part of HCM processes, companies often allocate large budgets for implementation of IT systems, but are unable to find out whether the solutions used actually support the performance of processes to a sufficient extent. A lot of money is spent on training courses, but managers are unable to determine the actual increase in competencies of employees that participated in them. Thus, it is often argued that investments in IT systems that support communication processes and in training courses do not result in the improvement of their performance, and training courses completed by employees do not lead to acquisition of competencies relevant to a company.

In order to achieve the expected performance and the quality of the functioning of the new methods of software development organizations it is necessary to apply new tools offering the ability to manage this process. One of such methods of evaluation is to examine the maturity level. The term of maturity is defined in the Dictionary of the Polish Language as: "...the state of having taken on the final form, achievement of the final stage of the development or process of shaping... " [10]. The concept of maturity was initially used in psychology to refer to "achievement by an individual of a certain desired mental or emotional state" [11]. In management studies, it appeared in the 1970s. [12]. It was accepted in the theory of management that apart from the extreme states of immaturity and maturity, there is also a certain number of intermediate states [13]. In the broadest sense, the concept of maturity can be examined in relation to an organization as a whole. In the context of management of processes performed within an organization, maturity can be viewed as managerial maturity, process maturity in the area of technology, quality, knowledge or culture as well as praxeology. Integrated maturity of an organization includes responsibility, reliance on trust in the business activity and striving after perfection. Specialized maturity takes into account process and technical approaches, quality, culture, management of knowledge, intellectual capital and, above all, management of human capital [14]. In the context of IT systems, the concept of maturity is usually associated with the field of software engineering [15].

In practice, this concept is most often examined in the following contexts:

- $\quad$ process maturity [16] [17], [18],

- $\quad$ project maturity [19],

- quality maturity,

- implementation maturity,

- different combinations, e.g. process and project maturity

As was already mentioned, in a modern organization, the performance of processes of HCM is inseparably connected with the use of appropriate IT systems that support communication processes, enable efficient management, automation, monitoring and optimization of these processes, allowing thereby higher levels of process maturity to be achieved. At the same time, IT systems, the process of their creation and degree of their use in an organization may also be evaluated [12]

For maturity assessment, flexible tailor-made models are used. Models designed to evaluate the level of maturity allow an organization to assess its methods and processes in accordance with the best practices of management and based on clearly defined external reference values. There is a range 
of models designed to evaluate the maturity level of models, from Crosby Quality Management Maturity Grid developed in the 1970s [20] to models dedicated to maturity evaluation developed based on internal assumptions of specific organizations. Models differ from each other in the scope of maturity level measurement which can be performed in various areas of an organization's activity. Many of them were taken into account in their research and described in their works by [21], [13].

Maturity modelling for the purpose of management and control of processes taking place in an organization is based on the method of evaluation of an organization. Its level of maturity can be evaluated on a scale from 0 (lack) to 5 (optimal). This approach is based on the maturity model developed in 1991 by Software Engineering Institute (SEI) a model for assessing maturity of development processes and potential (capability) of IT system (software) development (Capability Maturity Model for Software) CMM [22], [23].

HCM is a specific area, as it deals with processes connected with the most spontaneous and unpredictable of the resources at the disposal of an organization - its employees. The dynamics accompanying processes taking place in the HR sphere justifies creation of detailed models designed to assess the maturity level of IT systems connected with acquisition, creation and maintenance of human capital. Although there are no models that directly refer to maturity of such systems, there is a range of models that focus on the one hand on assessment of the maturity of IT systems, while on the other hand - on assessment of process maturity. There are also models designed to measure maturity of skills offered to an organization by its employees [24].

An example of such a model in the area of human capital management is PCMM. The model was developed to support processes connected with improvement of employees' skills which are one of the most important premises for creation of an organization's human capital and are regarded as key factors leading to success achieved by knowledge-based organizations. PCMM allows an organization to identify necessary activities to support employees' development depending on the current level of an organization. The model indicates competencies that are of key importance for proper operation of an organization in a changing environment, increasing effectiveness of HCM [25].

In available sources, researchers and practitioners give a lot of attention to the problem of maturity of IT systems. There are also a few models designed to assess maturity of systems connected with HCM in an organization.

One of more interesting examples is HCM applications implementation maturity model proposed by K. Jones [25] describing five levels of progressively more mature HCM applications implementation capability.

Presented model describes four levels of progressively more mature HCM applications implementation capability
1 st., Level: Technology-Centric - focused strictly on technology, with lacks a compelling business case to implement new software supporting HCM,

2 nd. Level: Process Automation - implementation process of information systems supporting HCM in organization providing a team implementing new software without ongoing and future software upgrades,

3 rd. Level: HR Customer-Centric - where implemented systems have inconsistent communication with stakeholders $\&$ audiences,

4 th., the highest Level: HR Customer-Centric - where software changes are driven through documentation of preexisting business, with project consolidation and rationalization of business processes and continual communication and engagement of stakeholders and audiences,

The above-described examples of the models, as well as many other presented in sources, enable assessment of the maturity of processes taking place in HCM, assessment of the maturity of "people capability", maturity of IT systems and implementation of HCM Information Systems (HCMIS) in an organization. These are, however, general models which treat HCM in a comprehensive way.

Effective HCM embraces an integrated approach that requires concepts and practices that are tested and proven. Practical management tools are required to help HR leaders diagnose problems quickly, then prioritize and implement reforms along an HCM maturity model in an environment that has many and, at times, conflicting sources of priorities.

The aim of the author was to attempt to match a method to assessment of process maturity of IT systems designed to support processes connected with communication processes taking place in HCM in an organization.

Although many general and specialized models designed to assess maturity in various contexts can be found, there are no detailed works that directly address research on maturity of IT systems that support the performance of communication processes as part of HCM in an organization. In order to fill this gap in methodology, it is necessary to develop a model and new method that enable assessment of maturity of such solutions. The basic task in this situation is to develop tools that will make it possible to determine maturity levels, and then to find out what is the maturity level of an examined solution.

\section{V.CONCLUSION}

The aim of the paper was to indicate tools that would enable organizations, an assessment of the adequacy of IT systems used to support communication processes in HCM. IT systems are a necessary element required to support processes connected with information exchange in HCM (e.g. knowledge distribution). Only the use of reliable solutions will allow an organization to create human capital which will give it a chance to gain competitive advantage. For an organization to be able to use appropriate solutions, it 
needs a reliable method for their assessment. The paper was an attempt to relate known methodologies for examining a system maturity to IT systems designed to support communication processes. It analyzed three selected models supporting assessment of maturity in three aspects connected with the selected research subject. This, however, does not exhaust the subject, although their use at a further stage of research creates significant chances in this aspect. My research shows that such systems function in almost every organization, with many organizations attaching great importance to them. However, given the lack of direct references in the academic literature to the issue of maturity of IT systems used to support communication processes in HCM, a few initial assumptions have to be made. The area of using IT systems to support HCM is nowadays intensively explored both in research and practice. There are already applications that support the different HCM processes, and over time they will fulfill an increasingly important role. Therefore, it is very important to ensure tools that will allow the usefulness of such solutions to be verified.

Given the volume of knowledge and literature, it is difficult to discuss all the aspects impacting the use the model to assess the maturity of HCMIS. None of the available maturity models takes into account all the conditions accompanying the introduction of modern communication technologies into HCM. It is thus necessary to create a new model that is based on the models available on the market, but, above all, takes into account all the conditions connected with implementation of HCMIS in an organization. Despite a large number of available models, not a single one that would enable a comprehensive assessment could be indicated. Necessary features were showed by a few models. It is thus justified to conduct appropriate research and propose a new model that would enable such assessment, defining maturity levels based on e.g. the level of knowledge representation. Although research is conducted, unexplored areas still exist. For instance, there are no solutions designed to assess maturity of IT systems that support communication processes and assist employees in their careers. However, with increasing availability of necessary tools, the possibilities to assess IT systems in their support of communication processes will increase, and the number of their successful applications in the area of HCM will undoubtedly grow.

An article is a background for my future researches focused on bridging the gap in methodology and creating new model that enable assessment of maturity of IT systems supporting communication processes in HCM.

\section{ACKNOWLEDGMENT}

The issues presented constitute a beginning part of the authors research into the aspect of improving communication processes in Human Capital Management

\section{REFERENCES}

[1] K. Legge, "Human Resource Management: Rhetorics and Realities", Basingstoke: Macmillan, 1995, pp 66-67

[2] E. Vaughan, "The trial between sense and sentiment: a reflection on the language of HRM", Journal of General Management, 19, 3, 1994 , pp. 20-32.

[3] "New Perspectives on Human Resource Management". John Storey Ed., Routledge. London. Distributed by The Law Book Company Limited, 1989

[4] J. Drucker, G. White, A. Hegewisch, L. Mayne "Between hard and soft HRM: human resource management in the construction industry", Construction Management and Economics, 14, 1996, pp. 405-416.

[5] T. Keenoy, P. Anthony, "HRM: metaphor, meaning and morality", In: P. Blyton and P. Turnbull Eds., Reassessing Human Resource Management, London: Sage, 1994, pp. 233-255

[6] J.L. Chatzkel, "Human capital. The rules of engagement are changing", in Lifelong learning in Europe, vol. 9, nr 3, 2004, pp. 139145.

[7] W. Kotarba (red.), "Ochrona wiedzy a kapitat intelektualny organizacji”, Polskie Wydawnictwo Ekonomiczne, Warszawa 2006, pp. 18-19.

[8] A. Sołtysik, "Zarządzanie Kapitałem Ludzkim z wykorzystaniem SAP $H C M^{\prime \prime}$ In: Wybrane Zagadnienia Wykorzystania Systemu SAP ERP w organizacji. M. Żytniewski Ed., Wydawnictwo Uniwersytetu Ekonomicznego w Katowicach, Katowice, 2015: pp. 219-258;

[9] A. Sołtysik, "Wspieranie procesów pozyskiwania, kreowania $i$ utrzymania kapitalu ludzkiego $w$ organizacji opartej na wiedzy. Wstęne wyniki badań”. In: Technologie Wiedzy W Zarządzaniu Publicznym, Wydawnictwo Naukowe UE w Katowicach, 2015

[10] Słownik Języka Polskiego SJP.PL

[11] T. E. Moffitt, "Adolescence-Limited and Life-Course-Persistent Antisocial-Behavior - A Developmental Taxonomy", Psychological Review, no. 100/1993, pp. 674-701

[12] W. Flieger, "Odkrywanie procesów jako składowa dojrzatości procesowej urzędów administracji samorzadowej”, In: Roczniki Kolegium Analiz Ekonomicznych, Szkoła Główna Handlowa, Warszawa, Zeszyt 33/2014

[13] D. Hillson, “Assessing Organizational Project Management Capability”, Journal of Facilities Management, no. 2/ 2003.

[14] E. Skrzypek, "Dojrzałość jakościowa organizacji wświetle teorii i doświadczen organizacji”, [http://www.marketingirynek.pl/files/ 1276809751/file/konferencja_5_2014.pdf]

[15] B. Begier, "Inżynieria oprogramowania ? problematyka jakości", Wyd. Politechniki Poznańskiej, Poznań 1999

[16] P. Grajewski, "Przestanki podejścia procesowego do projektowania i zarzadzania organizacja", In: J. Lichtarski Eds, Nowe kierunki w zarządzaniu przedsiębiorstwem - wiodące orientacje, Wydawnictwo UE we Wrocławiu, Wrocław, 2014.

[17] B.W. Cieśliński, "Doskonalenie procesowej orientacji przedsiębiorstw: model platformy treningu procesowego", Wydawnictwo UE we Wrocławiu, Wrocław, 2011, p.39

[18] G. Jokiel, "Podejście procesowe w zarządzaniu-geneza i kierunki rozwoju koncepcji”, In: Podejście procesowe w organizacjach, S. Nowosielski Ed., Wydawnictwo UE we Wrocławiu, Wrocław, 2009.

[19] J.R. Meredith, S.J. Mantel, "Project Management", John Wiley\& Sons, New York, 2000

[20] P. Crosby, "Quality is free", McGraw Hill, New York 1979, pp. 3233.

[21] P. Wyrozębski, M. Juchnowicz, W. Metelski, “Wiedza, dojrzałość, ryzyko wzarzadzaniu projektami", Oficyna Wydawnicza SGH, Warszawa 2012, pp. 127-128

[22] M.B. Chrissis, M. Konrad, S. Shrum, "CMMI for Development: Guidelines for Process Integration and Product Improvement", 3, Addison Wesley, 2011

[23] M. C. Paulk, B. Curtis, M. B. Chrisis, "Capability Maturity Model for Software, Version 1.1," Software Engineering Institute Technical Report, CMU/SEI-93-TR, February 24, 1993

[24] B. Curtis, W.E. Hefley, S. Miller. The People Capability Maturity Model: Guidelines for Improving the Workforce. Reading, MA: Addison Wesley Longman, 2002.

[25] K. Jones "http://www.bersin.com/Lexicon/details.aspx?id=12843" 